\title{
Common Terns Sterna hirundo incubating a Red-necked Grebe Podiceps grisegena egg
}

\author{
Fisktärnor Sterna hirundo ruvande ägg av \\ gråhakedopping Podiceps grisegena
}

\section{Lars Bern}

Department of Environmental Research and Monitoring, Swedish Museum of Natural History Correspondence: Tegnérgatan 15A, 75226 Uppsala, Sweden | lars.d.bern@outlook.com

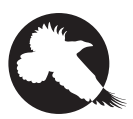

DURING A STUDY of Red-necked Grebes Podiceps grisegena in Lake Slagsmyren, Sweden, a pair of Common Terns Sterna hirundo were observed to have placed their two eggs on a deserted, floating nest of a Red-necked Grebe. Prior to this, the grebes had laid one egg of their own in the nest and this egg was included by the terns in their clutch and incubated by them. The species assignment of the odd egg was confirmed with DNA sequencing. A lack of natural nest sites for the terns to use at the lake could have caused this somewhat unusual choice of a nest site. I discuss possible explanations for adopting a foreign egg, including the adaptive behavioural response to roll an egg into the nest bowl to salvage lost eggs, the incubation stimulus that foreign eggs or egg-like objects potentially provide, and the limited egg discrimination abilities of Common Terns. The incubation of a foreign egg may reasonably be assumed to cost energy but to be of little benefit, if any, to the incubator.

Keywords: breeding | foreign eggs | egg recognition | egg adoption | nest usurpation

\section{Background, observations, and analyses}

The breeding of Red-necked Grebes Podiceps grisegena has been investigated in Lake Slagsmyren $\left(60.16^{\circ} \mathrm{N}\right.$, $\left.17.89^{\circ} \mathrm{E}\right)$, Sweden, since 2011 . The lake is a typical forest lake, its drainage basin is dominated by coniferous forests and the water is strongly humic. The population of grebes comprises $10-15$ pairs with territories widely spread over the lake. Common Terns Sterna hirundo appear regularly in the lake, and in the summer 2012 a 
breeding pair was noted in one of the grebe territories. However, the terns' choice of nesting ground and the placing of their eggs was somewhat surprising.

On 21 June 2012, the pair of Common Terns was observed sitting on a small bed of floating vegetation on the lake. Closer inspection was made from a boat on 24 June and revealed that the terns were breeding on a typical, floating nest of a Red-necked Grebe. The nest was well built with a platform and a cup, had good buoyancy, and was anchored in a sparse clump of common club-rush Schoenoplectus lacustris about $120 \mathrm{~m}$ from the nearest shore and over a water depth of about $1.5 \mathrm{~m}$ (Figure 1). The platform was made of fresh, green stems of club-rush and had a diameter of about $60 \mathrm{~cm}$, with cup about $20 \mathrm{~cm}$ in diameter. The cup was built of partly rotten plant material, typically collected by grebes from the bottom of the lake. The terns did not seem to have brought any additional material to the nest.

The inspection also revealed three eggs, one of which deviated markedly by lacking colouration and instead being entirely off-white (Figure 2). All the eggs were warm and were clearly being incubated by the terns. After the inspection, the terns immediately resumed their incubation. Unfortunately, the possible hatching of the eggs could not be followed.

The then deserted nest was revisited on 4 July. Of the three eggs only very small shell pieces, a few millimetres in size, could be found. To enable a species identification of the odd white egg, shell fragments were collected for DNA analysis. This determination was performed by Martin Irestedt and Niclas Gyllenstrand in 2015 at the Centre for Genetic Identification, Swedish Museum of Natural History, Stockholm, Sweden. A 105-basepair

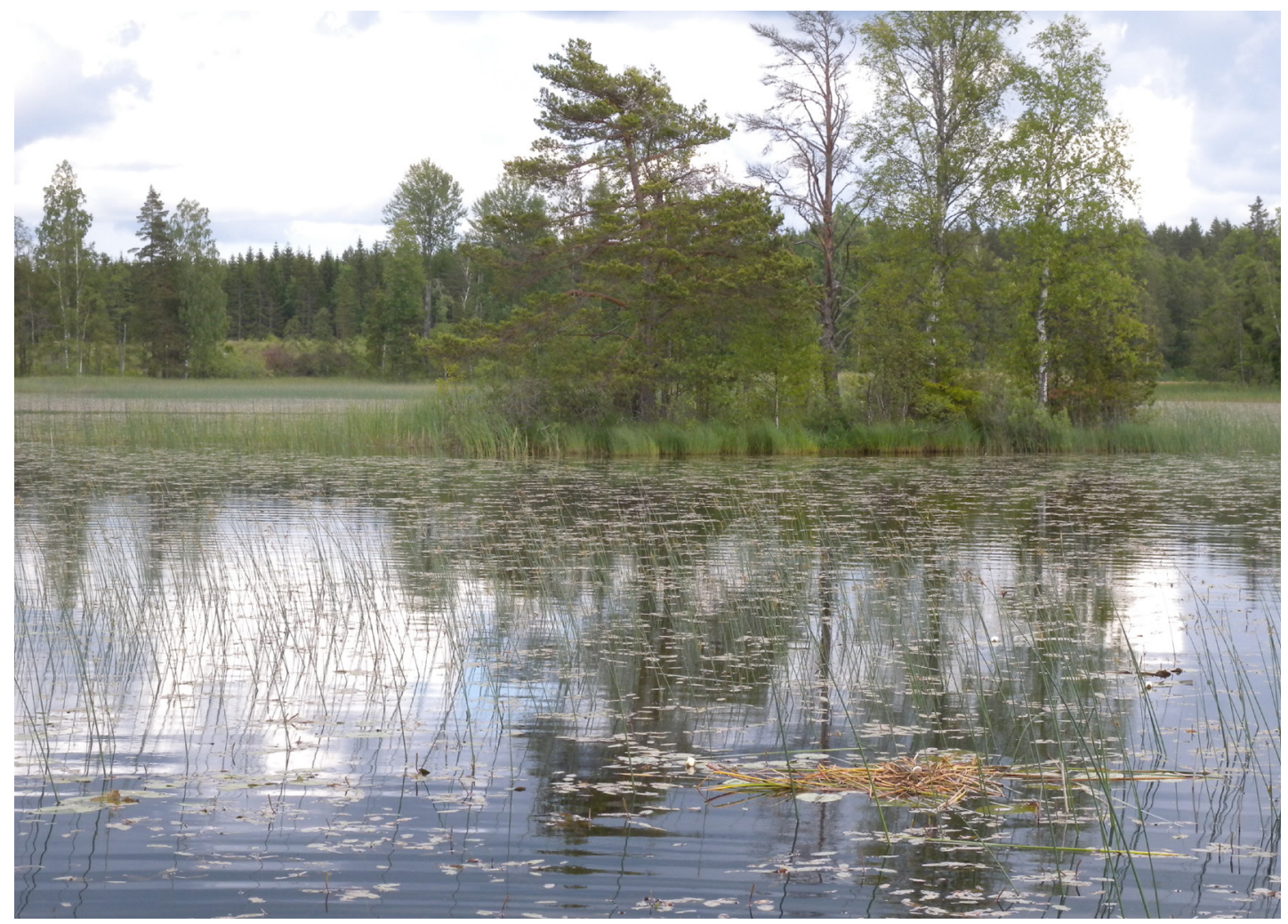

FIGURE 1. The floating nest of Red-necked Grebes Podiceps grisegena, anchored in a sparse clump of common club-rush, and used by a pair of Common Terns Sterna hirundo in 2012 at Lake Slagsmyren, Sweden.

- Det flytande boet av gråhakedopping Podiceps grisegena, förankrat i en gles sävrugge, och använt av ett par fisktärnor Sterna hirundo i Slagsmyren 2012 
fragment of the mitochondrial barcode marker $16 \mathrm{~S}$ rRNA was sequenced and compared to reference sequences in the Swedish DNA-key (https://dnakey.se/). The analysis revealed a $100 \%$ identity with both of two Rednecked Grebe reference sequences (cat. id. 20106609 and 20056171; E-value 0.0).

\section{Discussion}

\section{THE NEST}

The Common Tern often places its nest on firm, bare ground of lake shores or islands, or on sandbanks or suitable rocks in the water. Not uncommonly, they use floating material such as logs, chunks of plant material or depressed reed beds, or even nests deserted by other birds, e.g. Black-headed Gulls Croicocephalus ridibundus
(Cramp \& Simmons 1977, Glutz von Blotzheim \& Bauer 1987). However, the use of a floating nest of a Red-necked Grebe is probably not very common, and I have found no descriptions of this in the literature.

The nest that the terns had taken over was probably deserted by the grebes, as another nest with eggs and an incubating grebe was found in the same territory only about $25 \mathrm{~m}$ away. On several occaisons, I have observed that grebes in Lake Slagsmyren may desert their nest, even eggs, and build a new one. Possibly, the terns may have chased the grebes away from their nest, as Common Terns are known to be aggressive ( $\mathrm{Paz} \&$ Eshbol 2002).

\section{THE EGG}

Sometimes birds lay uncoloured (albinistic) eggs (Gross 1968). For example, Common Terns may have

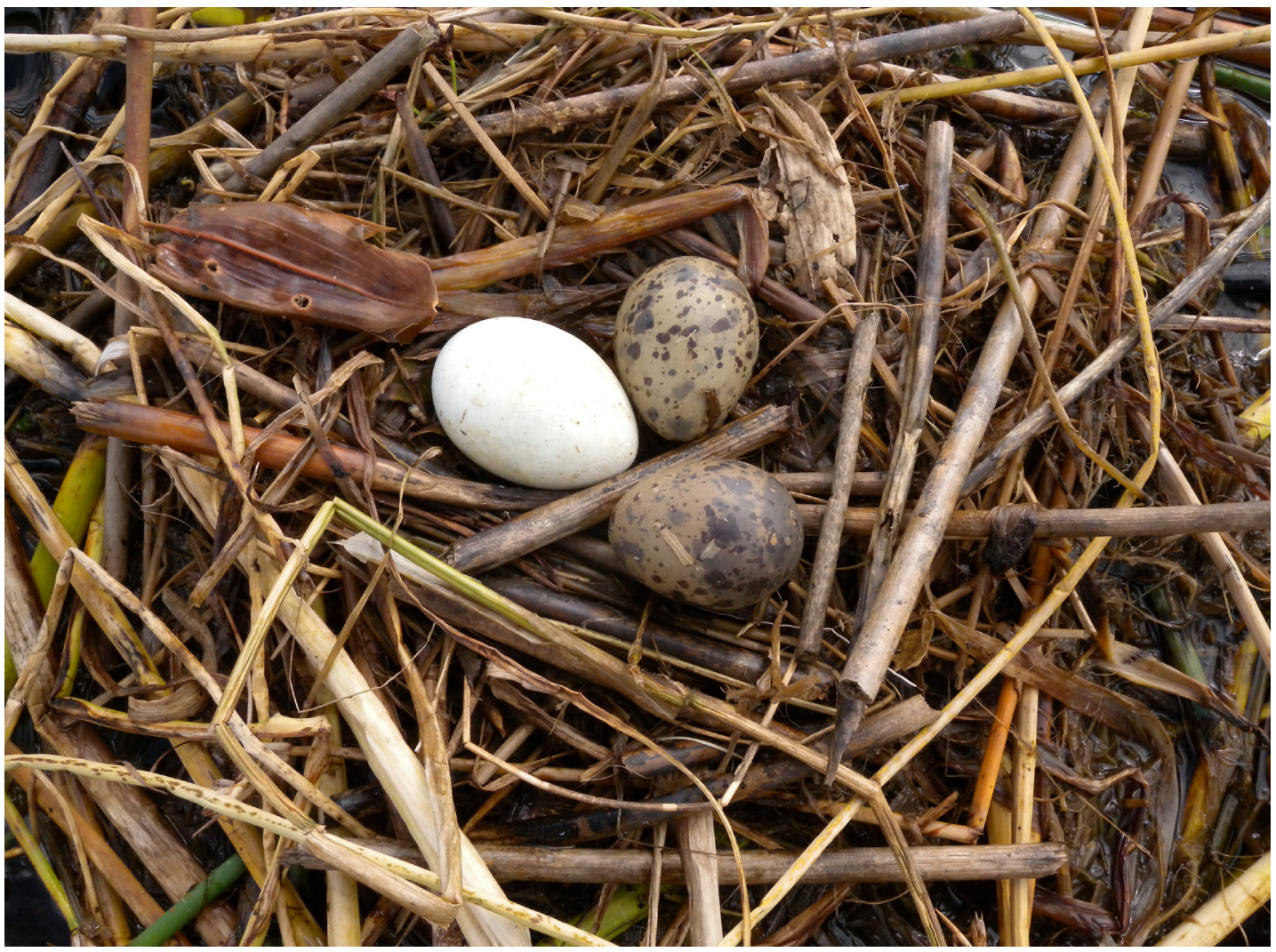

FIGURE 2. The Common Terns' Sterna hirundo clutch with two eggs of their own and a Red-necked Grebe Podiceps grisegena egg, Lake Slagsmyren, Sweden, in 2012.

- Fisktärnornas Sterna hirundo kull med två egna ägg och ett ägg av gråhakedopping Podiceps grisegena i Slagsmyren 2012. 
one albinistic egg in an otherwise naturally coloured clutch (Hays \& Parks 1993), or the entire clutch may be albinistic (Gross 1968). The three eggs in the Lake Slagsmyren nest were of unequal size, the white egg being the largest (Figure 2). However, Common Tern eggs vary in size, particularly in three-egg clutches, where the last-laid egg is often the smallest (Gemperle \& Preston 1955, Dunn 1972, Cramp \& Simmons 1977, Gochfeld 1977). Red-necked Grebe eggs are normally white and may partly overlap in size and shape with those of Common Terns (Gemperle \& Preston 1955, Dunn 1972, Gochfeld 1977, Cramp \& Simmons 1977, Glutz von Blotzheim \& Bauer 1987). Given that the terns were using a grebe nest, I suspected that the white egg could have been laid by the grebes. However, considering the overlapping size and shape between eggs of the two species, and the occurrence of albinistic eggs, DNA analysis was necessary to reach a conclusive species identification of the white egg.

\section{THE BEHAVIOUR}

The cause behind mixed interspecific clutches is not always clear in individual cases. Except obligate brood parasitism, several causes have been identified or at least suggested, e.g. interspecific facultative brood parasitism (Davies 2000, Krakauer \& Kimball 2009, Craik 2010), mistake (Sealy 1989, Fournier 2000, Clokie \& Cooper 2010, Motta etal. 2015, Witteveen et al. 2015), emergency egg dumping (Wiens 1971, Sealy 2015), and usurpation of another species' nest with eggs (Simpkin \& Gubanich 1991, Doyle \& Gough 1995, Dougall 1996, Dawson \& Bartolotti 1997, Petrassi et al. 1998, Dolonec 2002). Apart from obligate brood parasitism, the mechanisms are less well-known and cases seem to be uncommon. Yet, they are repeatedly observed and most probably underreported (Sealy 1989, Borgström 2005, Krakauer \& Kimball 2009, Craik 2010).

Several examples of mixed clutches exist among the charadriiform families of skuas (Stercorariidae) and gulls (Laridae; Sugden 1947, Clokie et al. 2010, Craik 2010, Motta et al. 2015, Witteveen et al. 2015). Also terns belong to the latter family, and present a few examples (Norton 1988, Cadiou \& Jacob 2010, Craik 2010). In the case presented here, the Common Terns had taken over a grebe nest with an egg, thus clearly an example of a nest takeover (nest usurpation). Two aspects of the terns' usurpation are important to consider: the nest takeover as such and the inclusion of the grebe egg in their clutch.

Taking over a nest built by another species can be problematic owing to species-specific requirements regarding the size and shape of the nest. Verified usurpations have been noted in secondary cavity breeders (with a natural habit of adopting a used nest) and ground-breeding ducks (Anseriformes), waders, gulls and terns (Charadriiformes; often with a similar type of nest within the groups). Similar nests make a takeover easier, but are a prerequisite rather than an explanation. Instead, the cause could be competition for cavities among cavity breeders or for space among dense populations of ducks, waders, gulls and terns. However, the current example with Common Terns represents a sparse population, presumably with low competition for nest sites. On the other hand, natural nest sites suitable for terns are rare at Lake Slagsmyren, which perhaps made the grebe nest attractive. I would argue that the terns were hardly attracted by a complete nest as such, but rather by suitable floating material, large enough, flat, bare, with good buoyancy, and at a sufficient distance from the shore to offer protection against terrestrial predators.

Usurpation of an alien species' nest has earlier been noted in at least one tern species, namely the Least Tern Sternula antillarum. In that case, the terns took over the nest of a Piping Plover Charadrius melodus pair with three eggs (Midura et al. 1991). Whether the nest was deserted or the terns drove the plovers away was uncertain. The terns laid two eggs and then incubated all five. In the case of these two species, both build similar nests despite the taxonomic difference-shallow depressions in the ground and sparsely lined-which probably facilitated the takeover. The cause of this nest takeover with the plover's eggs could not be identified.

Clearly, as in the case of the Least Tern, the foreign egg was included by the Common Terns in their own clutch. This inclusion by the Common Terns could have been caused by rolling the grebe egg into their own clutch. Such a behaviour is well-known among, for example, terns and can be regarded as an evolutionary adaptation to save lost eggs that have happened to roll outside the nest bowl (Marshall 1943). But why add a foreign egg?

Some tern species are able to recognize their own eggs, distinguish them from foreign eggs (even those of 
conspecifics) and reject them from their nest (Buckley \& Buckley 1972, Shugart 1987, Schaffner 1990). The Common Tern does not appear to have these abilities. It cannot distinguish its own eggs from those of conspecifics, does not reject such eggs that have been experimentally placed in its nest, and may even roll into its nest conspecifics' eggs that have been laid just outside it and incubate them together with its own (Marshall 1943). This behaviour may be particularly prominent during the initial part of the incubation, when the terns have not yet learnt to identify their own eggs (Schaffner 1990). These factors may explain why the grebe egg in the current case was not rejected from the platform or kept outside the terns' clutch, despite its deviating appearance.

The Common Terns' acceptance of the deviating grebe egg could also have been facilitated by the considerable variation in size, shape, colour, and pattern, which is typical for the eggs of Common Terns (Rowan et al. 1914, Watson et al. 1923, Cramp \& Simmons 1977; this study). Furthermore, many birds may include odd objects in their nests, e.g. stones and pieces of wood, which they 'incubate' together with their own eggs (Conover 1985, Langlois et al. 2012, Anderson \& Brush 2016). The reasons for, and potential function of, foreign objects of this kind are debated (Witteveen et al. 2015). Potentially, they may have a stimulating effect with less resettling and longer incubation bouts. Gulls and terns may include such objects in their nests, in particular pairs that lay only one or two eggs (and not a full clutch if the species' clutch size is larger). However, this behaviour of adding odd objects has not been investigated in full detail and conclusions concerning possible benefits are so far speculative (Coulter 1980). The behaviour described could also be interpreted as a misdirected rolling of eggs into the nest-the foreign objects are often egg-shaped and are common on the ground near the nest (Conover 1985, Witteveen et al. 2015). Possibly, this behaviour is seen more often among young, less experienced individuals (Langlois et al. 2012).

To conclude, a possible explanation for the observed behaviour of the Common Tern on Lake Slagsmyren is that, in the absence of alternatives, the Red-necked Grebe nest offered an attractive nesting place for the terns. Common Terns seem to have a certain inability to distinguish their own eggs from those of other birds or from some foreign objects. As a consequence, rolling the grebe egg into their own clutch may have been a mistake caused by a stimulus (the grebe egg) which did not represent a normal situation, but which corresponded so well to one that the behaviour was elicited. This is similar to the well-known situation where a stick with a painted red dot may trigger begging behaviour in a young gull. However, it cannot be excluded that the foreign egg was accepted immediately and that the terns laid their own eggs close to it without rolling behaviour, like the Least Terns possibly did (Midura et al. 1991). Thus, for the nest usurpation presented here, the nest takeover as such can be given a reasonable explanation, whereas it is hard to identify the most likely among several possible explanations for the egg inclusion. Incubating foreign eggs or other objects will reasonably involve an additional energetic cost with unknown benefits, if any. Even so, the rolling behaviour may still be evolutionarily selected if its advantages (saving a stray egg) outweigh its disadvantages.

Foreign eggs incubated by birds are always interesting to identify by species. This could be difficult to achieve if the egg is white, possibly albinistic, and if it overlaps in size and shape with the incubating species' own eggs. If the egg cannot be identified directly and if hatching cannot be followed, or fails, a possible way of avoiding a false identification is, as shown here, to analyse DNA from remaining shell fragments.

\section{Acknowledgements}

I thank Martin Irestedt and Niclas Gyllenstrand (Swedish Museum of Natural History), for the DNA analysis. Thord Fransson (Swedish Museum of Natural History) and an anonymous reviewer gave constructive criticism of an earlier draft of the manuscript. Jacob Angsten provided valuable assistance with the fieldwork.

\section{References}

Anderson A \& Brush J. 2016. Observation of American Oystercatchers (Haematopus palliatus) incubating a foreign object. The Wilson Journal of Ornithology 128: 939-941. https://doi.org/10.1676/15-190.1

Borgström E. 2005. Blandkullar mellan svartvit flugsnappare Ficedula hypoleuca, blåmes Parus caeruleus och talgoxe P. major. [Mixed clutches of Pied Flycatcher Ficedula hypoleuca, Blue Tit Parus caeruleus, and Great Tit P. major.] Ornis Svecica 15: 43-44. https:// doi.org/10.34080/os.v15.22304

Buckley PA \& Buckley FG. 1972. Individual egg and chick recognition 
by adult Royal Terns (Sterna maxima maxima). Animal Behaviour 20: 457-462. https://doi.org/10.1016/Sooo3-3472(72)80009-5

Cadiou B \& Jacob Y. 2010. Roseate Terns Sterna dougallii successfully rearing a young Sandwich Tern S. sandvicensis. Seabird 23: 139-142.

Conover MR. 1985. Foreign objects in bird nests. The Auk 102: 696-700.

Coulter MC. 1980. Stones: an important incubation stimulus for gulls and terns. The Auk 97: 898-899.

Clokie L \& Cooper J. 2010. Brown Skuas Stercorarius antarcticus incubate a Macaroni Penguin Eudyptes chrysolophus egg at Marion Island. Marine Ornithology 38: 59-6o.

Craik JCA. 2010. Mixed clutches at seabird colonies in west Scotland 1996-2009. Seabird 23: 41-52.

Cramp S \& Simmons KEL. 1977. Handbook of the Birds of Europe, the Middle East and North Africa. Oxford University Press, Oxford.

Davies NB. 20oo. Cuckoos, Cowbirds and Other Cheats. T \& AD Poyser Ltd, London.

Dawson RD \& Bortolotti GR. 1997. Misdirected incubation in American Kestrels: a case of competition for nest sites? The Wilson Bulletin 109: 732-734.

Dolenec Z. 2002. A mixed brood of Nuthatch (Sitta europaea) and Great Tit (Parus major) species. Natura Croatica 11: 103-105.

Dougall T. 1996. Oystercatcher apparently rearing Lapwings. Scottish Birds 18: 184 .

Doyle PAT \& Gough SJ. 1995. Arctic Skua incubating own egg and Common Gull eggs in Common Gull nest. Scottish Birds 18: 110 .

Dunn EK. 1972. Studies on terns with particular reference to feeding ecology. PhD thesis. Durham theses, Durham University. 190 pp. http://etheses.dur.ac.uk/8621/

Fournier MA. 20oo. Incidents of mixed clutches among Scaup and Ring-billed Gulls. Waterbirds 23: 114-116.

Gemperle ME \& Preston FW. 1955. Variation of shape in the eggs of the Common Tern in the clutch-sequence. The Auk 72: 184-198. https://doi.org/10.2307/4081424

Glutz von Blotzheim UN \& Bauer KM. 1987. Handbuch der Vögel Mitteleuropas. Aula-verlag, Wiesbaden.

Gochfeld M. 1977. Intraclutch egg variation: The uniqueness of the Common Tern's third egg. Bird-Banding 48: 325-332.

Gross AO. 1968. Albinistic eggs (white eggs) of some North American birds. Bird-Banding 39: 1-6. https://doi.org/10.2307/4511431

Hays H \& Parkes KC. 1993. Erythristic eggs in the Common Tern. Journal of Field Ornithology 64: 341-345.

Krakauer AH \& Kimball RT. 2009. Interspecific brood parasitism in galliform birds. Ibis 151: 373-381. https://doi. org/10.1111/j.1474-919X.2009.00916.x

Langlois LA, Murböck K, Bulla M \& Kempenaers B. 2012. Unusual incubation: Long-billed Dowitcher incubates mammalian bones. Ardea 100: 206-210. https://doi.org/10.5253/078.100.0213
Marshall N. 1943. Factors in the incubation behavior of the Common Tern. The Auk 6o: 574-588. https://doi.org/10.2307/4079421

Midura AM, Beyer SM \& Kilpatrick HJ. 1991. An observation of human-induced adoption in Piping Plovers. Journal of Field Ornithology 62: 429-431.

Motta LM, Paritsis J \& Alarcón PAE. 2015. Flying Steamer-Duck (Tachyeres patachonicus) egg found in a Kelp Gull (Larus dominicanus) nest in northwestern Patagonia. Ornitologia Neotropical 26: $113-116$.

Norton RL. 1988. Extra-egg clutches and inter-specific egg-dumping of the Roseate Tern (Sterna dougallii) in the West Indies. Florida Field Naturalist 16: 67-70.

Paz U \& Eshbol Y. 2002. Adoption of Black-winged Stilt Chicks by Common Terns. The Wilson Bulletin 114: 409-412. https://doi.org/1 0.1676/0043-5643(2002)114[0409:AOBWSC]2.0.CO;2

Petrassi F, Sorace A, Tanda F \& Consiglio C. 1998. Mixed clutches of Blue Tits Parus caeruleus and Great Tits Parus major in nest boxes in Central Italy. Ornis Svecica 8: 49-52. https://doi.org/10.34080/ os.v8.22303

Rowan W, Parker KM \& Bell J. 1914. On homotyposis and allied characters in eggs of the Common Tern. Biometrika 10: 144-168. https://doi.org/10.1093/biomet/10.1.144

Schaffner FC. 1990. Egg recognition by Elegant Terns (Sterna elegans). Colonial Waterbirds 13: 25-30. https://doi.org/10.2307/1521417

Sealy SG. 1989. Incidental "egg dumping" by the House Wren in a Yellow Warbler nest. The Wilson Bulletin 101: 491-493.

Sealy SG. 2015. Egg laying in inappropriate nests by the Brownheaded Cowbird (Molothrus ater): acts of parasitism or emergency egg dumping? Canadian Field-Naturalist 129: 60-69. https://doi. org/10.22621/cfn.v129i1.1668

Shugart GW. 1987. Individual clutch recognition by Caspian Terns, Sterna caspia. Animal Behaviour 35: 1563-1565. https://doi. org/10.1016/Sooo3-3472(87)80030-1

Simpkin JL \& Gubanich AA. 1991. Ash-Throated Flycatchers (Myiarchus cinerascens) raise Mountain Bluebird (Sialia currucoides) young. Condor 93: 461-462. https://doi.org/10.2307/1368969

Sugden JW. 1947. Excotic eggs in nests of California Gulls. Condor 49: 93-96. https://doi.org/10.2307/1364356

Watson DMS, Watson KM, Pearson HS \& Karn MN. 1923. The nest and eggs of the Common Tern (S. fluviatilis). Biometrika 15: 294-345. https://doi.org/10.1093/biomet/15.3-4.294

Wiens JA. 1971. "Egg dumping" by the Grasshopper Sparrow in a Savannah Sparrow nest. The Auk 88: 185-186. https://doi. org/10.2307/4083990

Witteveen M, Brown M \& Ryan PG. 2015. Pseudo-egg and exotic egg adoption by Kelp Gulls Larus dominicanus vetula. African Zoology 50: 59-61. https://doi.org/10.1080/15627020.2015.1021172 


\section{Svensk sammanfattning}

Vid studier av häckningen hos gråhakedoppingar Podiceps grisegena i sjön Slagsmyren, Uppland, observerades under 2012 ett par fisktärnor Sterna hirundo som utnyttjat ett övergivet, flytande bo av doppingarna för sin egen häckning. Orsaken till att tärnorna valt denna boplats kan ha varit att naturliga boplatser, som passar fisktärnors krav, saknas i sjön. Tärnorna hade lagt två normalt färgade ägg, men i boet fanns också ett tredje helt vitt ägg. Fisktärnor kan ibland lägga albinistiska (dvs. vita) ägg, men ägget hade även kunnat vara lagt av en gråhakedopping, vars ägg också är vitt och kan överlappa i storlek och form med fisktärnors.

Den eventuella kläckningen av äggen kunde inte följas. För att säkerställa det vita äggets identitet gjordes en DNA-analys av insamlade äggskärvor i det slutligen övergivna boet. Analysen visade med säkerhet att ägget var lagt av en gråhakedopping.
Alla tre äggen ruvades av tärnorna. Att ruva ett främmande ägg kostar energi, som rimligen är till liten eller ingen nytta för ruvaren. Orsaken till att tärnorna inkluderat det främmande ägget i sin kull är inte uppenbar. Måsfåglar, däribland fisktärnor, är kända för att kunna rulla in och därmed rädda ägg, som råkat komma utanför bokanten. Samtidigt tycks fisktärnor ha en viss oförmåga att känna igen sina egna ägg och skilja dem från andras. Åsynen av det vita ägget kan (av misstag) ha utlöst ett sådant beteende, varpå det rullades in i boet, liknande den välkända situation där en pinne med en rödmålad prick kan utlösa ett tiggeribeteende hos en trutunge. Ibland hittas i fisktärnors bon stenar eller träbitar bland de egna äggen, vilka fåglarna "ruvar", ofta äggliknande till storlek och form och vanligt förekommande i boets närhet. Möjligen har de adderats till kullen genom samma mekanism, där de udda föremålen uppfattats som förlupna ägg.

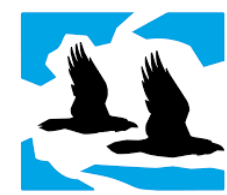

BirdLife Sverige

Ornis Svecica (ISSN 2003-2633) is an open access, peer-reviewed scientific journal published in English and Swedish by BirdLife Sweden. It covers all aspects of ornithology, and welcomes contributions from scientists as well as non-professional ornithologists. Accepted articles are published at no charge to the authors. Read papers or make a submission at os.birdlife.se.

Ornis Svecica (ISSN 2003-2633) är en fritt tillgänglig granskad vetenskaplig tidskrift som ges ut på svenska och engelska av BirdLife Sverige. Den täcker ornitologins alla områden och välkomnar bidrag från såväl forskare som icke-professionella ornitologer. Accepterade uppsatser publiceras utan kostnad för författarna. Läs uppsatser eller skicka in ditt bidrag på os.birdlife.se. 